\title{
BONE MARKERS IN ARTHROPATHIES
}

\author{
Roxana Răduț, Alexandra M. Crăciun and Ciprian N. Silaghi \\ Department of Medical Biochemistry, Iuliu Hatieganu University of Medicine and Pharmacy, \\ Cluj-Napoca, Romania
}

\begin{abstract}
SUMMARY - Bone endures a lifelong course of construction and destruction, with bone marker (BM) molecules released during this cycle. The field of measuring BM levels in synovial fluid and peripheral blood is a cardinal part of bone research within modern clinical medicine and has developed extensively in the last years. The purpose of our work was to convey an up-to-date overview on synovial fluid and serum BMs in the most common arthropathies.
\end{abstract}

Key words: Synovial fluid; Bone and bones; Joint diseases

\section{Introduction}

In adults, bone is an active organ that undergoes a constant remodeling process of formation and resorption. Therefore, these two reverse activities can be measured with the help of specific bone markers (BMs). Since information on bone remodeling cycle could represent an early indicator of pathologic changes in bones, measuring BM levels can provide important data on therapeutic response, faster than measuring bone mass.

Arthropathies describe a large domain of joint diseases, which can be classified depending on etiologic factors. The prevalence of inflammatory joint diseases has been rising continuously and environmental factors seem to play an important role. The main symptoms of arthritis (pain, redness, and swelling of the joints) often limit the ability to perform everyday activities, being the leading cause of disability.

Lately, more attention has been paid to studying diagnostic methods of arthropathies. On the one hand, several studies on osteoarthritis (OA), rheumatoid arthritis (RA) and osteoporosis have been published with the purpose of helping the clinician make an

Correspondence to: Ciprian N. Silaghi, $M D, P h D$, Iuliu Haţieganu University of Medicine and Pharmacy, 6 Pasteur Street, 400349, Cluj-Napoca, Romania

E-mail: silaghi.ciprian@umfcluj.ro

Received October 16, 2018, accepted November 20, 2018 early diagnosis and achieve better treatment results. On the other hand, some conditions are still overlooked and undertreated. This phenomenon has been observed in the calcium pyrophosphate deposition (CPPD) disease, where clinicians meet difficulties in diagnosing and treating the condition.

The aim of this review was to grant an overview of up-to-date knowledge collected over the past 15 years regarding synovial fluid (SF) and serum BMs in the most common arthropathies. Attention was focused on osteocalcin (OC), beta-crosslaps, osteoprotegerin (OPG) and matrix Gla protein (MGP) levels in OA, crystal arthropathies, RA, osteoporosis and inflammatory joint disease, also including relevant genetic markers.

\section{Bone Markers}

As it is well known, there are two different types of BMs: formation BMs (e.g., procollagen type I extension peptides, bone-specific alkaline phosphatase and $\mathrm{OC}$ ) and resorption BMs (e.g., tartrate-resistant acid phosphatase, collagen cross-link molecules, crosslinked telopeptides of collagen I, hydroxyproline, hydroxylysine-glycoside, OPG and bone sialoprotein).

\section{Beta-crosslaps}

Bone matrix is produced by osteoblasts and contains predominantly type 1 collagen. During bone re- 
sorption, collagen breakdown leads to $\mathrm{N}$ and $\mathrm{C}$-telopeptides ${ }^{1}$. Two fragments result from the C-telopeptide end: ICTP (cross-linked carboxyterminal telopeptide of type I collagen) and CTX (C-terminal cross-linked telopeptide of type I collagen). Both fragments are used as clinical markers and can be measured in serum, $\mathrm{SF}$ or urine by specific immunoassays. ICTP and CTX undergo different degradation pathways, therefore these two markers help in distinguishing different bone pathologies ${ }^{2}$. Serum beta telopeptide immunoassays have also been used to evaluate bone destruction in various diseases, e.g., cancer $^{3-5}$, endocrine pathologies ${ }^{6-8}$, or in hemodialysis patients ${ }^{9,10}$.

\section{Matrix Gla protein}

Matrix Gla protein is an extracellular matrix protein, member of the mineral-binding Gla protein family, found in humans in cartilage, bone, vascular smooth muscle cells, but also in animals ${ }^{11}$. It acts as an inhibitor of ectopic tissue calcification.

Recently, Marulanda et al. ${ }^{12}$ demonstrated in a mouse model that MGP deficiency causes septal chondrocyte apoptosis, thus involving MGP in nasal septum development. Since there are phenotypic similarities between mice and humans, the absence of MGP in mice can be a solid base for understanding and treating craniofacial anomalies.

The polymorphism of MGP gene screening was published in 2000 by Herrmann et al. ${ }^{13}$, but the focus of research was on studying the association between MGP rs4236 and rs1800801 genetic variants and arterial wall calcification ${ }^{14}$. The gene codes a vitamin-K dependent protein that regulates the amount of cartilage mineralization by regulating chondrocyte maturation and bone formation ${ }^{15}$. Also, Nakatani et al. ${ }^{16} \mathrm{dem}-$ onstrated that MGP could lead to bone demineralization due to high levels of magnesium in plasma.

The activity of MGP as a calcification inhibitor requires two post-translational modifications, i.e. $\gamma$-glutamate carboxylation and serine phosphorylation. MGP contains 9 glutamate residues, 5 of them being $\gamma$-carboxylated by vitamin $\mathrm{K}$-dependent $\gamma$-glutamate carboxylase, thus contributing to calcium binding and crystal growth control ${ }^{17}$.

Studies have shown that serine phosphorylation has also an important role in MGP functionality ${ }^{18}$. Both post-translational modifications lead to different types of MGP species, i.e. phosphorylated (pMGP), dephosphorylated (dpMGP), carboxylated (cMGP), uncarboxylated (ucMGP), or different combinations of these. Unfortunately, not all the conformations can be measured, but their circulating levels may reflect the degree of calcification in the vascular wall ${ }^{19}$.

Radioimmunoassay and enzyme-linked immunosorbent assays have been used to assess circulating MGP in order to establish its prognostic value in cardiovascular diseases and patients with end-stage renal disease $^{20}$. Cranenburg et al. ${ }^{19}$ compared two monoantibody and two dual-antibody MGP assays in several pathologies. Although the dual-antibody assay measuring dephosphorylated-uncarboxylated MGP (dp-ucMGP) was appropriate to evaluate vascular vitamin K status, dp-ucMGP levels were also elevated in patients with gout, some individuals with RA and systemic lupus erythematosus.

Matrix Gla protein was studied in a wide range of diseases from tumoral pathologies ${ }^{21}$, including breast cancer $^{22}$, renal diseases ${ }^{23}$ and arterial calcification ${ }^{24}$. In the last years, utilization of MGP as a BM has attracted much attention from researchers, as discussed below.

\section{Osteocalcin}

Another vitamin $\mathrm{K}$-dependent protein, OC, is synthesized by osteoblasts and has an important role in bone formation. Gamma-glutamyl carboxylase and vitamin $\mathrm{K}$ (acting as a coenzyme) convert uncarboxylated OC into carboxylated OC. However, in humans, the carboxylation process is not fully completed, as the uncarboxylated $\mathrm{OC}$ is to be found in bone and serum. The majority of $\mathrm{OC}$ is deposited in bone matrix, where the main function is not only to bind calcium and help bone formation, but also to regulate bone cell activity. It was demonstrated that a small proportion of OC (20\%) reaches the bloodstream and is rapidly cleared in a population with preserved kidney function ${ }^{25}$.

\section{Osteoprotegerin}

Osteoprotegerin, also known as osteoclastogenesis inhibitory factor, is an affiliate of the tumor necrosis factor (TNF) receptor superfamily member $11 \mathrm{~B}$, acting in human body as a cytokine of the TNF receptor superfamily ${ }^{26}$. The TNF/TNF receptor superfamily is composed of more than 40 members. Their main role was proven not only to control genes for different cel- 
lular processes (differentiation, survival and apoptosis), but also to coordinate numerous organ functions ${ }^{27}$.

Osteoprotegerin follows a very complex bone remodeling pathway, which implies another member of TNF superfamily, the receptor activator of nuclear factor- $\kappa \beta$ (RANK) and its ligand (RANKL). RANK and RANKL binding leads to transformation of proosteoclast into mature osteoclasts, causing bone resorption. OPG controls osteoclastogenesis via competing with RANK and inhibiting the RANKL-RANK interaction. As a result, it prevents bone destruction. Furthermore, OPG has the ability to interact with TNF-related apoptosis-inducing ligand (TRAIL), another TNF family member, with the consequence of inducing apoptosis in numerous cancer cells ${ }^{28}$.

Osteoprotegerin expression was found in a considerable variety of tissues in the human body, either upor down-regulating them, e.g., osteoblasts, endothelial cells, smooth muscle cells, dendritic cells ${ }^{29}$. In addition, several studies highlighted the OPG function in the pathogenesis of atherosclerosis ${ }^{30}$, diabetes mellitus and renal dysfunction ${ }^{31}$.

\section{Arthropathies}

The term arthropathy includes any disease affecting the joint. Depending on the etiologic factor, there are multiple classifications of joint diseases in the literature. Lambert ${ }^{32}$ simplifies them into four categories, as follows: degenerative or OA, inflammatory, autoimmune, and septic arthritis. Articular cartilage primarily contains type II collagen, proteoglycans, chondrocytes and water. A constant equilibrium among these components is needed to maintain a healthy articular cartilage. Regardless of the cause that disrupts the equilibrium, joint diseases may cause swelling, pain, stiffness, and could lead not only to overall mobility reduction, but also compromise the quality of life ${ }^{33}$. Hereunder, several bone and cartilage pathologies are briefly reviewed.

\section{Osteoarthritis}

Osteoarthritis is considered the most common chronic join disease that affects around $10 \%$ of men and $18 \%$ of women aged over 60 years $^{34}$. The etiology of $\mathrm{OA}$ is different when referring to primary and secondary OA. For several years, great efforts have been invested in the study of risk factors. Besides age and sex, which seem to be the major ones, there are others to be mentioned, i.e. genetics, bone metabolism, obesity, diet, ethnicity and joint-level risk factors. Despite all efforts, the prevalence of OA has been continuously rising $^{35}$. The main characteristic of OA is the loss of articular cartilage and subchondral bone sclerosis, which leads to activity-related pain, morning joint stiffness, and finally loss of joint function ${ }^{36}$. The focus of recent research was on early identification of the pathology. In this respect, Mobasheri and Henrotin ${ }^{37}$ studied OA biomarkers to diagnose, predict or assess the patient physical condition.

Osteoarthritis may not only occur as a primary form, but also as secondary form, depending on the identifiable cause. The most interesting approach to this issue has been proposed by Yamaguchi et al $^{38}$ in a research of hip OA due to osteonecrosis of the femoral head, rapidly destructive arthrosis and developmental dysplasia of the hip. In that study, bone and cartilage marker levels in SF were analyzed and compared. The overall measurement results showed a bone formative condition in patients with osteonecrosis of the femoral head and elevated osteoclastic activity in patients with rapidly destructive arthrosis, thus adding a new introspective into the pathophysiology and clinical evolution of each disease ${ }^{38}$.

\section{Inflammatory and autoimmune arthritis}

The most common type of autoimmune arthritis is RA. On the one hand, the pathology describes inflammation of the synovial membrane causing joint swelling, but on the other hand, RA can lead to extra-articular pathologies. The most commonly affected joints are small and medium joints. A typical patient has symmetrical inflammation in the wrist and metacarpophalangeal joints. Genetic factor was found to account for $50 \%$ risk of developing $\mathrm{RA}^{39}$. In their study, Gland et al. ${ }^{40}$ investigated the role of epigenetics and considered both genetics and epigenetics to contribute slightly to RA development.

Another important autoimmune arthritis is psoriatic arthritis (PS). In terms of differentiation between RA and PS, Verheul et al. ${ }^{41}$ concluded on the occurrence of autoantibodies in RA and their absence in PS to be the key, but various markers should be longitudinally assessed in future studies.

Juvenile idiopathic arthritis (JIA), previously known as juvenile rheumatoid arthritis is one of the 
most common disorders found in children and adolescents. The pathology is difficult to diagnose due to the lack of pediatric symptoms. There is no reliable and specific blood test to establish the diagnosis, and treatment may consist of intra-articular steroid injections. Carrasco et al. ${ }^{42}$ investigated changes in bone formation and resorption markers from 198 corticosteroidfree children with JIA with daily oral calcium supplementation. They found that serum OC level, among other hormones and minerals, was significantly lower in the calcium supplementation group.

\section{Crystal arthropathies}

Crystal arthropathies are skeletal diseases caused by deposition of mineral compounds mainly in joints but also in periarticular tissues ${ }^{43}$. Gout and chondrocalcinosis (also known as pseudogout, commonly caused by CPPD) are the most frequently seen forms of crystal arthropathies. Crystal composition, shape and birefringence detected by polarized light microscopy, first suggested by McCarty et al..$^{44}$ in 1962 , is now the gold standard in establishing the diagnosis ${ }^{45}$. Gout presents negative birefringence needle-like monosodium urate crystals, whereas weakly positive, rhomboid calcium pyrophosphate crystals are typical for chondrocalcinosis. Moreover, McQueen et al. ${ }^{46}$ studied the importance of imaging diagnosis in crystal arthropathies. Thereby, ultrasonography, radiography, computed tomography, dual energy computer tomography and magnetic resonance imaging could be useful tools to identify crystal depositions in joints.

The presence of crystals in joint cavity results in synovitis and pain. Although gout is linked to hyperuricemia and the pathologic mechanism of pseudogout remains mainly unknown, there is evidence in literature that gout and chondrocalcinosis may coexist. The association of gout and chondrocalcinosis in the same joint was found in $1998^{47}$. Ten years later, another coexistence case of gout and chondrocalcinosis in the same joints and in both hands was described ${ }^{48}$. Clinical recognition and differentiation of gout and CPPD from other arthropathies may be the key to an accurate treatment. Acute gout and CPPD symptoms may be controlled with similar drugs such as colchicine, nonsteroidal anti-inflammatory drugs and corticosteroids. It is known that the use of urate lowering therapy has a substantial effect on controlling chronic gout. On the contrary, approaching chronic CPPD may be problematic to clinician due to the high rate of comorbidities $^{49}$. No significant effect of methotrexate was found in chronic CPPD, thus the patient should be referred to a rheumatologist when choosing thera$\mathrm{py}^{50}$. On the other hand, researchers highlighted the anti-inflammatory effect of nanoparticles in treating chronic crystal-induced arthropathies, and by virtue of beneficial effects, they should be considered an efficient therapy option ${ }^{51}$.

\section{Bone Markers in Arthropathies and Osteoporosis}

Bone and joint destruction in rheumatic diseases can be quantified by analyzing BM levels in serum and/or SF. As any biological marker, measuring BMs may present some limitations such as pre-analytical, analytical and post-analytical variability, especially when measuring resorption markers. According to Hlaing et al..$^{52}$, there are some steps that clinicians could follow in order to reduce BM variability and improve clinical outcomes. Despite their variability, many $\mathrm{BMs}$ are used in clinical practice to diagnose or monitor endocrine, oncologic, renal and rheumatic disorders that have influence on bone diseases ${ }^{53}$.

Recently, ever more attention has been paid to BM measurements in SF. Synovial fluid is a viscous, protein-rich fluid produced by the synovial membrane. Besides reducing friction between opposing surfaces of cartilage and shock absorption, SF is a medium for breakdown products secreted in joint diseases, which may be first detected in SF before serum. Several methods could be helpful in diagnosing arthropathies. In a recent paper by Dubey et al. ${ }^{54}$, the presence of reactive arthritis metabolites in SF was investigated with nuclear magnetic resonance spectroscopy in order to bring a better clinical perspective. Furthermore, a study of genetic markers from 2010 showed that SF microRNAs may represent valuable biomarkers for $\mathrm{RA}$ and $\mathrm{OA}^{55}$.

However, there still is a significant potential for improvements in identifying reliable BMs. As an example, combined measuring of ucMGP in serum and SF may be considered a useful joint inflammatory marker in patients with arthritis ${ }^{56}$. For understanding frequent pathologies such as OA, RA, PS or JIA, proteomics in SF based on mass spectrometry techniques is becoming more popular in BMs validation ${ }^{57}$. Early 
diagnosis of joint diseases using SF biomarkers has become a strong future perspective that will help physicians achieve better treatment for patients ${ }^{58}$.

\section{Osteoarthritis: a long studied disease}

The incidence of knee $\mathrm{OA}$ is likely to increase due to aging and the increasing rate of overweight and obesity in general population. Previous studies suggested that low vitamin $\mathrm{K}$ status was associated with higher OA prevalence and incidence ${ }^{59}$. It is already well established that $\mathrm{OA}$ is characterized by changes in bone cells along with mineralization of the matrix. Articular chondrocytes in OA undergo hypertrophy ${ }^{60}$, with vitamin $\mathrm{K}$ being essential to prevent soft tissue mineralization, thus a low circulating level of MGP leads to development of cartilage calcification ${ }^{61}$.

Related to MGP, fetuin is also a calcium binding protein and an inhibitor of calcium phosphate salt formation, synthesized by the liver and secreted into the bloodstream. In bone, fetuin interacts with cMGP, forming a complex via calcium phosphate that is released into the bloodstream as a fetuin-MGP complex $^{62}$. In 2010, a study among OA patients ${ }^{63}$ showed an important difference in MGP production between normal chondrocytes and chondrocytes isolated from OA cartilage; normal cells synthesized functional cMGP, whereas OA cells produced primarily ucMGP. Wallin et al. ${ }^{63}$ demonstrated not only that cartilage contained fetuin, but also that fetuin uptake by chondrocytes in cell culture had a similar mechanism with fetuin uptake by cultured vascular smooth muscle cells. Moreover, they revealed the fetuin-MGP complex to be present in normal chondrocyte vesicles but not in the vesicles from OA chondrocytes. From the outcomes of this study, it is possible to conclude that the absence of cMGP and cMG-fetuin complex in OA cells and vesicles could explain increased mineralization of osteoarthritic cartilage.

The possible association between circulating vita$\min \mathrm{K}, \mathrm{dp}$-ucMGP (the inactive conformation of MGP, related to vitamin K deficiency) and structural features of the knee (as assessed by magnetic resonance imaging) were evaluated by Shea et al. ${ }^{64}$ using a crosssectional and longitudinal approach. They carried out a study to find if lower plasma vitamin $\mathrm{K}$ and higher dp-ucMGP could be associated with a higher prevalence and progression of knee OA. They found a positive association between plasma dp-ucMGP and the presence of knee OA features, but there was no clear evidence for association between dp-ucMGP and OA progression $^{64}$.

An intriguing approach was proposed in 2015 by Park et al. ${ }^{65}$, who showed that a fluoro-microbeads guiding chip may be a new method of detecting the CTX-II BM in serum and urine to establish the diagnosis of OA. Another study from 2016 on rabbits with knee $\mathrm{OA}^{66}$ demonstrated the efficiency of short thrust needling (close-to-bone needling) plus electroacupuncture in healing pathologic knee cartilage tissue by regulating cartilage vitamin $\mathrm{K}$ dependent gamma-glutamyl carboxylase expression, which resulted in lower levels of serum ucMGP. Instead, in humans, ucMGP levels measured in SF might serve as a biomarker for assessing knee OA progression ${ }^{67}$. Serum OPG (among other bone turnover markers) has also been referred to as a valuable biologic marker in predicting knee $\mathrm{OA}$ radiographic severity ${ }^{68}$.

\section{Chondrocalcinosis and bone markers}

Chondrocalcinosis is a rheumatic disease that leads to acute and chronic arthritis due to accumulation of calcium pyrophosphate dihydrate crystals in joints. In the last years, the EULAR CPPD Task Force has suggested CPPD as the umbrella term for all instances of calcium pyrophosphate (CPP) crystal deposition which includes asymptomatic CPPD, OA with CPPD, acute CPP crystal arthritis (replacing the term pseudogout) and chronic CPP crystal inflammatory arthritis. Chondrocalcinosis or cartilage calcification (CC) is only used for imaging or histologic examination and may occur not only in CPPD, but also in other joint pathologies. Similar to gout, CPPD associates various clinical presentations such as asymptomatic CPPD, OA with CPPD, acute and chronic CPP crystal arthritis ${ }^{69}$.

Calcium pyrophosphate crystals deposited in joints require inorganic pyrophosphate $(\mathrm{PPi})$ and calcium. All the PPi found in the body is synthesized exclusively through endogenous pathway. Chondrocytes produce $\mathrm{PPi}$, which uses ankylosis transporter $(\mathrm{ANKH}$ in humans and ANK transporter in mice) to pass the cell membrane. ANKH gene is located on the short (p) arm of chromosome 5 and loss of its function resulted in low $\mathrm{PPi}$, whereas overexpression of the gene generated high levels of $\mathrm{PPi}$ and subsequent $\mathrm{CPPD}^{70}$. Using immunohistochemistry and in situ hybridiza- 
tion techniques, Uzuki et al. ${ }^{11}$ showed the number of ANKH-positive cells in joint tissues from patients with CPPD to be higher than in OA patients without crystal deposition or controls.

Although CPPD has been reported as sporadic and primarily affecting the elderly, younger individuals with familial CPPD have also been described in the literature ${ }^{70}$. Interest in the field of genetics appears to increase as more studies of ANKH protein in familial CPPD diseases have been published in the last years. It was established that mutation in CCAL 2 locus on chromosome 5 was linked to an autosomal-dominant form of CPPD, but mutation on chromosome 8 (CCAL 1) was also related to $\mathrm{CPPD}^{72,73}$. A subsequent study revealed that mutation in TNFRSF11B gene encoding OPG might lead to an association of $\mathrm{OA}$ and chondrocalcinosis ${ }^{74}$; in the study conducted by William et al. ${ }^{75}$ in 2018, CCAL1 locus on chromosome 8 was identified as TNFRSF11B (OPG) gene.

Calcium pyrophosphate crystals induce synovial inflammation and other effects on joint tissues on the account of stimulation of prostaglandin $\mathrm{E}$ and matrix metalloproteinase production. All these changes in the cartilage will eventually lead to cartilage degeneration $^{76}$.

The gold standard in CPPD diagnosis is microscopic analysis of SF by visualizing the positive birefringence rhomboid-shaped crystals. An early diagnosis of microcrystalline arthritis can usually be performed by using noninvasive methods. The importance of ultrasonography in the differential diagnosis of early arthritis has been highlighted recently in a case report of a male suffering from Gitelman syndrome, in which cartilage calcification could be considered an early marker ${ }^{77}$, but additional studies are still required.

It is already known that CPPD is an underdiagnosed and undertreated condition. However, studies on using BMs from $\mathrm{SF}$ for diagnostic purposes are still lacking. An example of measuring molecular fragments in SF is presented by Lohmander $\mathrm{et} \mathrm{al.}{ }^{78}$ in patients with OA and other types of knee arthritis, among which pseudogout was mentioned. Strong evidence for high levels of cross-linked C-telopeptide fragments of type II collagen (CTX-II) being released soon after joint injury or arthritis had been proved. Therefore, CTX-II levels may be an important step that should be considered in diagnostic and treatment protocol.

\section{Rheumatoid arthritis}

Patients with RA have a higher risk of developing secondary osteoporosis. From this perspective, Matuszewska and Szechiński ${ }^{79}$ assessed specific BM levels in RA patients undergoing therapy for osteogenesis and proved that reduced levels of OC might indicate a lower rate of osteogenesis. In RA patients, several serum and synovial BMs have been used for prognosis and clinical diagnosis. Although the results were promising, more research in BMs validation is necessary before obtaining a definitive answer for prediction of therapeutic response. As reported by Marotte et $a l .{ }^{80}, \mathrm{CTX}-\mathrm{II}$ levels might be useful to monitor treatment and evaluation of RA.

\section{Osteoporosis}

Osteoporosis was defined as deterioration of bone mass and is associated with increased risk of fracture, bone fractures being manifest in females over 65 years of age and to a lesser extent in males over $65^{81}$. Osteoporotic fractures pose a major problem worldwide; therefore, the Bone Marker Standards Working Group ${ }^{82}$ proposes the specific markers of bone resorption and bone formation be taken into consideration in all future studies. Since CTX is a BM which presents an advantage of having low biologic variability when collected in EDTA-containing tubes, it is considered to be the bone resorption marker of choice ${ }^{83}$.

Among other BMs, lower levels of OC and CTX were found in overweight postmenopausal women with diabetes type $2^{84}$, and higher MGP levels in postmenopausal women with calcified minor carotid stenosis, regardless of the presence of osteopenia and osteoporosis ${ }^{85}$.

Moreover, in 2016, it was shown that BMs may currently be used not only in the assessment of fracture risk but also in monitoring osteoporotic treatment ${ }^{86}$.

Recently, considerable attention has been paid to $\mathrm{BM}$ polymorphisms in osteoporosis. A study on femoral neck bone in men demonstrated the loss of bone mineral density to be associated with MGP -7G>A and MGP Thr83Ala polymorphisms ${ }^{87}$. Therefore, the authors suggest that some MGP variants may influence the expression of MGP gene and the progression of bone loss could be predicted at an earlier stage. Another interesting approach to this issue has been proposed by Ling et al. ${ }^{88}$ in a study among Chinese popu- 
lation, suggesting that rs 1800247 polymorphism in OC gene may influence serum total OC levels and the risk of osteoporosis.

\section{Conclusions}

Bone and joint destruction can be quantified by analyzing BM levels in serum and SF. Studies have shown that breakdown products may first be detected in SF before serum, therefore analyzing SF should be further considered.

Bone markers are a useful accessory for the diagnosis and therapeutic monitoring of bone metabolic disorders, but their use has to be tempered by known limitations in clinical utility and by preanalytical variables that complicate the interpretation. BMs could complete the results of imaging techniques, thus contributing to faster and accurate diagnosis. With development of new techniques and new markers, the future of arthropathy management sounds promising.

\section{References}

1. Bilezikian JP, Raisz LG, Martin TJ. Principles of Bone Biology. $3^{\text {rd }}$ ed. Amsterdam (NL): Elsevier/Academic Press; 2008.

2. Garnero P, Ferreras M, Karsdal MA, Nicamhlaoibh R, Risteli J, Borel O, et al. The type I collagen fragments ICTP and CTX reveal distinct enzymatic pathways of bone collagen degradation. J Bone Miner Res. 2003;18(5):859-67. https://doi. org/10.1359/jbmr.2003.18.5.859

3. Vallet S, Hoyle NR, Kyle RA, Podar K, Pecherstorfer M. A role for bone turnover markers $\beta$-CrossLaps (CTX) and aminoterminal propeptide of type I collagen (PINP) as potential indicators for disease progression from MGUS to multiple myeloma. Leuk Lymphoma. 2018;59(10):2431-8. https://doi.org/ 10.1080/10428194.2017.1421757

4. Weissensteiner J, Babušíková E. Bone metabolism of the patient with a malignant melanoma during the entry examination and the check-up of whole-body bone scintigraphy. Prague Med Rep. 2016;117(2-3):129-34. https://doi.org/10.14712/ 23362936.2016.14

5. Chen Y,Xu G, Yang F. Effect of neoadjuvant chemotherapy on the serum levels of bone turnover markers in women with early-stage breast cancer. PLoS One. 2015;10(4):e0126053. https://doi.org/10.1371/journal.pone.0126053

6. Verheyen N, Grübler MR, Meinitzer A, Trummer C, Schwetz $\mathrm{V}$, Amrein $\mathrm{K}$, et al. Effect of eplerenone on markers of bone turnover in patients with primary hyperparathyroidism - the randomized, placebo-controlled EPATH trial. Bone. 2017; 105:212-7. https://doi.org/10.1016/j.bone.2017.08.030
7. Li Y, Chang J, Jiang T. Serum level of chemerin and bone mineral density in patients with Graves disease. 2017;42(8):94752. https://doi.org/10.11817/j.issn.1672-7347.2017.08.012

8. Maggi S, Siviero P, Brocco E, Albertin M, Romanato G, Crepaldi G. Vitamin D deficiency, serum leptin and osteoprotegerin levels in older diabetic patients: an input to new research avenues. Acta Diabetol. 2014;51(3):461-9. https://doi.org/ 10.1007/s00592-013-0540-4

9. Milinković NLj, Majkić-Singh NT, Mirković DD, Beletić AD, Pejanović SD, Vujanić ST. Relation between 25(OH)-vitamin $\mathrm{D}$ deficiency and markers of bone formation and resorption in haemodialysis patients. Clin Lab. 2009;55(9-10):333-9.

10. Jean G, Lafage-Proust MH, Souberbielle JC, Lechevallier S, Deleaval P, Lorriaux C, et al. Severe secondary hyperparathyroidism in patients on haemodialysis is associated with a high initial serum parathyroid hormone and beta-CrossLaps level: results from an incident cohort. PLoS One. 2018;13(6): e0199140. https://doi.org/10.1371/journal.pone.0199140

11. Luo G, D'Souza R, Hogue D, Karsenty G. The matrix Gla protein is a marker of the chondrogenesis cell lineage during mouse development. J Bone Miner Res. 1995;10:325-34. https: //doi.org/10.1002/jbmr.5650100221

12. Marulanda J, Eimar H, McKee MD, Berkvens M, Nelea V, Roman $\mathrm{H}$, et al. Matrix Gla protein deficiency impairs nasal septum growth, causing midface hypoplasia. J Biol Chem. 2017; 292(27):11400-12. https://doi.org/10.1074/jbc.M116.769802

13. Herrmann SM, Whatling C, Brand E, Nicaud V, Gariepy J, Simon A, et al. Polymorphisms of the human matrix gla protein (MGP) gene, vascular calcification, and myocardial infarction. Arterioscler Thromb Vasc Biol. 2000;20(11):2386-93. https:// doi.org/10.1161/01.atv.20.11.2386

14. Wang Y, Chen J, Zhang Y, Yu W, Zhang C, Gong L, et al. Common genetic variants of MGP are associated with calcification on the arterial wall but not with calcification present in the atherosclerotic plaques. Circ Cardiovasc Genet. 2013;6(3):271-8. https://doi.org/10.1161/CIRCGENETICS.113.000003

15. Borgonio-Cuadra VM, González-Huerta NC, Rojas-Toledo EX, Morales-Hernández E, Pérez-Hernández N, RodríguezPérez JM, et al. Genetic association analysis of Osteopontin and matrix Gla protein genes polymorphisms with primary knee osteoarthritis in Mexican population. Clin Rheumatol. 2019;38 (1):223-8. https://doi.org/10.1007/s10067-018-4146-7

16. Nakatani S, Mano H, Ryanghyok IM, Shimizu J, Wada M. Excess magnesium inhibits excess calcium-induced matrix mineralization and production of matrix gla protein (MGP) by ATDC5 cells, Biochem Biophys Res Commun. 2006;348(3): 1157-62. https://doi.org/10.1016/j.bbrc.2006.07.180

17. Hackeng TM, Rosing J, Spronk HM, Vermeer C. Total chemical synthesis of human matrix Gla protein. Protein Sci. 2001;10:864-70. https://doi.org/10.1110/ps.44701

18. Schurgers LJ, Barreto DV, Barreto FC, Liabeuf S, Renard C, Magdeleyns EJ, et al. The circulating inactive form of matrix gla protein is a surrogate marker for vascular calcification in chronic kidney disease: a preliminary report. Clin J Am Soc Nephrol. 2010;5(4):568-75. https://doi.org/10.2215/CJN.07081009 
19. Cranenburg EC, Koos R, Schurgers LJ, Magdeleyns EJ, Schoonbrood TH, Landewé RB, et al. Characterisation and potential diagnostic value of circulating matrix Gla protein (MGP) species. Thromb Haemost. 2010;104(4):811-22. https: //doi.org/10.1160/TH09-11-0786

20. Cranenburg EC, Vermeer C, Koos R, Boumans ML, Hackeng TM, Bouwman FG, et al. The circulating inactive form of matrix Gla protein (ucMGP) as a biomarker for cardiovascular calcification. J Vasc Res. 2008;45(5):427-36. https://doi.org/ 10.1159/000124863

21. Gheorghe SR, Crăciun AM. Matrix Gla protein in tumoral pathology. Clujul Med. 2016;89(3):319-21. https://doi.org/ 10.15386/cjmed-579

22. Tiago DM, Conceição N, Caiado H, Laizé V, Cancela ML. Matrix Gla protein repression by miR-155 promotes oncogenic signals in breast cancer MCF-7 cells. FEBS Lett. 2016;590(8): 1234-41. https://doi.org/10.1002/1873-3468.12155

23. Miyata KN, Nast CC, Dai T, Dukkipati R, LaPage JA, Troost $\mathrm{JP}$, et al. Renal matrix Gla protein expression increases progressively with CKD and predicts renal outcome. Exp Mol Pathol. 2018;105(1):120-9. https://doi.org/10.1016/j.yexmp. 2018.07.001

24. Gourgas O, Marulanda J, Zhang P, Murshed M, Cerruti M. Multidisciplinary approach to understand medial arterial calcification. Arterioscler Thromb Vasc Biol. 2018;38(2):363-72. https://doi.org/10.1161/ATVBAHA.117.309808

25. Wen L, Chen J, Duan L, Li S. Vitamin K dependent proteins involved in bone and cardiovascular health. Mol Med Rep. 2018;18(1):3-15. https://doi.org/10.3892/mmr.2018.8940

26. Venuraju SM, Yerramasu A, Corder R, Lahiri A. Osteoprotegerin as a predictor of coronary artery disease and cardiovascular mortality and morbidity. J Am Coll Cardiol. 2010;55 (19):2049-61. https://doi.org/10.1016/j.jacc.2010.03.013

27. Ware CF. The TNF Superfamily 2008. Cytokine Growth Factor Rev. 2008;19:183-6. https://doi.org/10.1016/j.cytogfr.2008.05.001

28. Pérez de Ciriza C, Lawrie A, Varo N. Osteoprotegerin in cardiometabolic disorders. Int J Endocrinol. 2015;2015:564934. https://doi.org/10.1155/2015/564934

29. Silva I, Branco JC. Rank/Rankl/opg: literature review. Acta Reumatol Port. 2011;36(3):209-18.

30. McGonigle JS, Giachelli CM, Scatena M. Osteoprotegerin and RANKL differentially regulate angiogenesis and endothelial cell function. Angiogenesis. 2009;12(1):35-46. https://doi. org/10.1007/s10456-008-9127-z

31. Altinova AE, Toruner F, Akturk M, Bukan N, Yetkin I, Cakir $\mathrm{N}$, et al. Relationship between serum osteoprotegerin, glycemic control, renal function and markers of atherosclerosis in type 2 diabetes. Scand J Clin Lab Invest. 2011;71(4):340-3. https:// doi.org/10.3109/00365513.2011.570868

32. Lambert DG. Drugs used to treat joint and muscle disease. Anaesth Intensive Care Med. 2015;16(3):140-4. https://doi. org/10.1016/j.mpaic.2014.12.001
33. Hunter H, Ryan MS. Osteoarthritis, Knee. Treasure Island (FL): StatPearls Publishing; 2018.

34. Glyn-Jones S, Palmer AJ, Agricola R, Price AJ, Vincent TL, Weinans H, et al. Osteoarthritis. Lancet. 2015;386(9991): 376-87. https://doi.org/10.1016/S0140-6736(14)60802-3

35. Johnson VL, Hunter DJ. The epidemiology of osteoarthritis. Best Pract Res Clin Rheumatol. 2014;28(1):5-15. https://doi. org/10.1016/j.berh.2014.01.004

36. Pereira D, Ramos E, Branco J. Osteoarthritis. Acta Med Port. 2015;28(1):99-106.

37. Mobasheri A, Henrotin Y. Biomarkers of (osteo)arthritis. Biomarkers. 2015;20(8):513-8. https://doi.org/10.3109/135475 0X.2016.1140930

38. Yamaguchi R, Yamamoto T, Motomura G, Ikemura S, Iwasaki $\mathrm{K}$, Zhao $\mathrm{G}$, et al. Bone and cartilage metabolism markers in synovial fluid of the hip joint with secondary osteoarthritis. Rheumatology (Oxford). 2014;53(12):2191-5. https://doi. org/10.1093/rheumatology/keu253

39. Scott DL, Wolfe F, Huizinga TW. Rheumatoid arthritis. Lancet. 2010;376(9746):1094-108. https://doi.org/10.1016/ S0140-6736(10)60826-4

40. Glant TT, Mikecz K, Rauch TA. Epigenetics in the pathogenesis of rheumatoid arthritis. BMC Med. 2014;12:35. https:// doi.org/10.1186/1741-7015-12-35

41. Verheul MK, Fearon U, Trouw LA, Veale DJ. Biomarkers for rheumatoid and psoriatic arthritis. Clin Immunol. 2015;161 (1):2-10. https://doi.org/10.1016/j.clim.2015.04.005

42. Carrasco R, Lovell DJ, Giannini EH, Henderson CJ, Huang B, Kramer S, et al. Biochemical markers of bone turnover associated with calcium supplementation in children with juvenile rheumatoid arthritis. Arthritis Rheum. 2008;58(12):3932-40. https://doi.org/10.1002/art.24041

43. Fuerst M, Zustin J, Rüther W. Crystal arthropathies. Pathologe. 2011;32(3):193-9. https://doi.org/10.1007/s00292-011$1422-6$

44. McCarty DJ, Kohn NN, Faires JS. The significance of calcium phosphate crystals in the synovial fluid of arthritic patients: the pseudogout syndrome. I Clinical aspects. Ann Intern Med. 1962;56:711-37. https://doi.org/10.7326/0003-4819-56-5-711

45. Lioté F. Diagnosis of crystal-induced arthritis. Presse Med. 2011;40(9 Pt 1):869-76. https://doi.org/10.1016/j.lpm.2011. 07.003

46. Teh J, McQueen F, Eshed I, Plagou A, Klauser A. Advanced imaging in the diagnosis of gout and other crystal arthropathies. Semin Musculoskelet Radiol.2018;22(2):225-36. https:// doi.org/10.1055/s-0038-1639484

47. De Bari C, Lapadula G, Cantatore FP. Coexisting psoriatic arthritis, gout, and chondrocalcinosis. Scand J Rheumatol. 1998; 27(4):306-9. https://doi.org/10.1080/030097498442442

48. Coutier F, Sondag M, Wendling D. Coexisting gout and chondrocalcinosis on hand radiograph. J Rheumatol. 2018;45(5): 723-4. https://doi.org/10.3899/jrheum.171154 
49. Sidari A, Hill E. Diagnosis and treatment of gout and pseudogout for everyday practice. Prim Care. 2018;45(2):213-36. https://doi.org/10.1016/j.pop.2018.02.004

50. Finckh A, Mc Carthy GM, Madigan A, Van Linthoudt D, Weber M, Neto D, et al. Methotrexate in chronic-recurrent calcium pyrophosphate deposition disease: no significant effect in a randomized crossover trial. Arthritis Res Ther. 2014;16(5):458. https://doi.org/10.1186/s13075-014-0458-4

51. Zamudio-Cuevas Y, Fernández-Torres J, Martínez-Nava GA, Martínez-Flores K, López-Reyes A. Emergent nanotherapies in microcrystal-induced arthritis. Int Immunopharmacol. 2018;61: 197-203. https://doi.org/10.1016/j.intimp.2018.06.007

52. Hlaing TT, Compston JE. Biochemical markers of bone turnover - uses and limitations. Ann Clin Biochem. 2014;51 (Pt 2):189-202. https://doi.org/10.1177/0004563213515190

53. Greenblatt MB, Tsai JN, Wein MN. Bone turnover markers in the diagnosis and monitoring of metabolic bone disease. Clin Chem. 2017;63(2):464-74. https://doi.org/10.1373/clinchem. 2016.259085

54. Dubey D, Chaurasia S, Guleria A, Kumar S, Modi DR, Misra $\mathrm{R}$, et al. Metabolite assignment of ultrafiltered synovial fluid extracted from knee joints of reactive arthritis patients using high resolution NMR spectroscopy. Magn Reson Chem. 2019; 57(1):30-43. https://doi.org/10.1002/mrc.4763

55. Murata K, Yoshitomi H, Tanida S, Ishikawa M, Nishitani K, Ito $\mathrm{H}$, et al. Plasma and synovial fluid microRNAs as potential biomarkers of rheumatoid arthritis and osteoarthritis. Arthritis Res Ther. 2010;12(3):R86. https://doi.org/10.1186/ar3013

56. Silaghi CN, Fodor D, Cristea V, Crăciun AM. Synovial and serum levels of uncarboxylated matrix Gla-protein (ucMGP) in patients with arthritis. Clin Chem Lab Med. 2011;50(1): 125-8. https://doi.org/10.1515/CCLM.2011.713

57. Mahendran SM, Oikonomopoulou K, Diamandis EP, Chandran V. Synovial fluid proteomics in the pursuit of arthritis mediators: an evolving field of novel biomarker discovery. Crit Rev Clin Lab Sci. 2017;54(7-8):495-505. https://doi.org/10.1080/ 10408363.2017.1408561

58. Nguyen LT, Sharma AR, Chakraborty C, Saibaba B, Ahn ME, Lee SS. Review of prospects of biological fluid biomarkers in osteoarthritis. Int J Mol Sci. 2017;18(3):601. https://doi. org/10.3390/ijms18030601

59. Zhang Y, Jordan JM. Epidemiology of osteoarthritis. Clin Geriatr Med. 2010;26:355-69. https://doi.org/10.1016/j.cger. 2010.03.001

60. von der Mark K, Kirsch T, Nerlich A, Kuss A, Weseloh G, Gluckert $\mathrm{K}$, et al. Type $\mathrm{X}$ collagen synthesis in human osteoarthritic cartilage. Indication of chondrocyte hypertrophy. Arthritis Rheum. 1992;35:806-11. https://doi.org/10.1002/art. 1780350715

61. Luo G, Ducy P, McKee MD, Pinero GJ, Loyer E, Behringer $\mathrm{RR}$, et al. Spontaneous calcification of arteries and cartilage in mice lacking matrix GLA protein. Nature. 1997;386:78-81. https://doi.org/10.1038/386078a0
62. Price PA, Nguyen TM, Williamson MK. Biochemical characterization of the serum fetuin-mineral complex. J Biol Chem. 2003;278:22153-60. https://doi.org/10.1074/jbc.M300739200

63. Wallin R, Schurgers LJ, Loeser RF. Biosynthesis of the vitamin $\mathrm{K}$-dependent matrix Gla protein (MGP) in chondrocytes: a fetuin-MGP protein complex is assembled in vesicles shed from normal but not from osteoarthritic chondrocytes. Osteoarthr Cartilage. 2010;18(8):1096-103. https://doi.org/10.1016 /j.joca.2010.05.013

64. Shea MK, Kritchevsky SB, Hsu FC, Nevitt M, Booth SL, Kwoh CK, et al. The association between vitamin $\mathrm{K}$ status and knee osteoarthritis features in older adults: the Health, Aging and Body Composition Study. Osteoarthr Cartilage. 2015; 23(3):370-8. https://doi.org/10.1016/j.joca.2014.12.008

65. Park YM, Kim SJ, Lee KJ, Yang SS, Min BH, Yoon HC. Detection of CTX-II in serum and urine to diagnose osteoarthritis by using a fluoro-microbeads guiding chip. Biosens Bioelectron. 2015;67:192-9. https://doi.org/10.1016/j.bios.2014.08.016

66. Xi XF, Li XZ, Liu F, Fu NN, Ren Y, Yang XG, et al. Effects of short thrust needing plus electroacupuncture intervention on cartilage tissue in rabbits with knee osteoarthritis. Zhen Ci Yan Jiu. 2016;41(2):124-30.

67. Bing W, Feng L. Attenuated synovial fluid uncarboxylated matrix Gla-protein (ucMGP) concentrations are linked with radiographic progression in knee osteoarthritis. Adv Clin Exp Med. 2015;24(6):1013-7. https://doi.org/10.17219/acem/33824

68. Min S, Wang C, Lu W, Xu Z, Shi D, Chen D, et al. Serum levels of the bone turnover markers dickkopf-1, osteoprotegerin, and TNF- $\alpha$ in knee osteoarthritis patients. Clin Rheumatol. 2017;36(10):2351-8. https://doi.org/10.1007/s10067017-3690-x

69. Zhang W, Doherty M, Bardin T, Barskova V, Guerne PA, Jansen TL, et al. European League Against Rheumatism recommendations for calcium pyrophosphate deposition. Part I: Terminology and diagnosis. Ann Rheum Dis. 2011;70(4):563-70. https://doi.org/10.1136/ard.2010.139105

70. Doherty M, Hunter DJ, Bijlsma H, Arden N, Dalbeth N. Oxford Textbook of Osteoarthritis and Crystal Arthropathy. New York, NY: Oxford University Press; 2016.

71. Uzuki M, Sawai T, Ryan LM, Rosenthal AK, Masuda I. Upregulation of ANK protein expression in joint tissue in calcium pyrophosphate dihydrate crystal deposition disease. J Rheumatol. 2014;41(1):65-74. https://doi.org/10.3899/jrheum.111476

72. Netter P, Bardin T, Bianchi A, Richette P, Loeuille D. The ANKH gene and familial calcium pyrophosphate dihydrate deposition disease. Joint Bone Spine. 2004;71(5):365-8. https:// doi.org/10.1016/j.jbspin.2004.01.011

73. Williams CJ, Pendleton A, Bonavita G, Reginato AJ, Hughes $\mathrm{AE}$, Peariso $\mathrm{S}$, et al. Mutations in the amino terminus of ANKH in two US families with calcium pyrophosphate dihydrate crystal deposition disease. Arthritis Rheum. 2003;48: 2627-31. https://doi.org/10.1002/art.11133

74. Ramos YF, Bos SD, van der Breggen R, Kloppenburg M, Ye K, Lameijer EW, et al. A gain of function mutation in TNFRS- 
F11B encoding osteoprotegerin causes osteoarthritis with chondrocalcinosis. Ann Rheum Dis. 2015;74(9):1756-62. https://doi.org/10.1136/annrheumdis-2013-205149

75. Williams C, Qazi U, Bernstein M, Charniak A, Gohr C, Mitton-Fitzgerald E, et al. Mutations in osteoprotegerin account for the CCAL1 locus in calcium pyrophosphate deposition disease. Osteoarthr Cartilage. 2018;26(6):797-806. https://doi. org/10.1016/j.joca.2018.03.005

76. Liu YZ, Jackson AP, Cosgrove SD. Contribution of calciumcontaining crystals to cartilage degradation and synovial inflammation in osteoarthritis. Osteoarthr Cartilage. 2009;17 (10):1333-40. https://doi.org/10.1016/j.joca.2009.04.022

77. Zabotti A, Della Siega P, Picco L, Quartuccio L, Bassetti M, De Vita S. Gitelman syndrome disclosed by calcium pyrophosphate deposition disease: early diagnosis by ultrasonographic study. Reumatismo. 2016;68(1):53-5. https://doi.org/10.4081/ reumatismo.2016.884

78. Lohmander LS, Atley LM, Pietka TA, Eyre DR. The release of crosslinked peptides from type II collagen into human synovial fluid is increased soon after joint injury and in osteoarthritis. Arthritis Rheum. 2003;48(11):3130-9. https://doi.org/10.1002 /art.11326

79. Matuszewska A, Szechiński J. Evaluation of selected bone metabolism markers in rheumatoid arthritis patients. Adv Clin Exp Med. 2013;22(2):193-202.

80. Marotte H, Gineyts E, Miossec P, Delmas PD. Effects of infliximab therapy on biological markers of synovium activity and cartilage breakdown in patients with rheumatoid arthritis. Ann Rheum Dis. 2009;68(7):1197-200. https://doi.org/10.1136/ ard.2008.096057

81. Pavić R, Hnatešen D, Margetić P. Epidemiology of adult fractures in eastern Croatia by cause of injury, fracture location and type of treatment. Acta Clin Croat. 2017;56(3):494-504. https://doi.org/10.20471/acc.2017.56.03.17
82. Wheater G, Elshahaly M, Tuck SP, Datta HK, van Laar JM. The clinical utility of bone marker measurements in osteoporosis. J Transl Med. 2013;11:201. https://doi.org/10.1186/14795876-11-201

83. Stokes FJ, Ivanov P, Bailey LM, Fraser WD. The effects of sampling procedures and storage conditions on short-term stability of blood-based biochemical markers of bone metabolism. Clin Chem. 2011;57(1):138-40. https://doi.org/10.1373/clinchem. 2010.157289

84. Bilić-Ćurčić I, Makarović S, Mihaljević I, Franceschi M, Jukić $\mathrm{T}$. Bone mineral density in relation to metabolic syndrome components in postmenopausal women with diabetes mellitus type 2. Acta Clin Croat. 2017;56(1):58-63. https://doi.org/ 10.20471/acc.2017.56.01.09

85. Silaghi CN, Fodor D, Crăciun AM. Circulating matrix Gla protein: a potential tool to identify minor carotid stenosis with calcification in a risk population. Clin Chem Lab Med. 2013; 51(5):1115-23. https://doi.org/10.1515/cclm-2012-0329

86. Shetty S, Kapoor N, Bondu JD, Thomas N, Paul TV. Bone turnover markers: emerging tool in the management of osteoporosis. Indian J Endocrinol Metab. 2016;20(6):846-52. https: //doi.org/10.4103/2230-8210.192914

87. Tunón-Le Poultel D, Cannata-Andía JB, Román-García P, Díaz-López JB, Coto E, Gómez C, et al. Association of matrix Gla protein gene functional polymorphisms with loss of bone mineral density and progression of aortic calcification. Osteoporos Int. 2014;25(4):1237-46. https://doi.org/10.1007/ s00198-013-2577-1

88. Ling Y, Gao X, Lin H, Ma H, Pan B, Gao J. A common polymorphism rs1800247 in osteocalcin gene was associated with serum osteocalcin levels, bone mineral density, and fracture: the Shanghai Changfeng Study. Osteoporos Int. 2016;27(2): 769-79. https://doi.org/10.1007/s00198-015-3244-5

\section{KOŠTANI BILJEZI U ARTROPATIJAMA}

\section{R. Rădut, A. M. Crăciun i C. N. Silaghi}

Kost podliježe stalnoj izgradnji i razgradnji tijekom čitavog života. Tijekom tog procesa oslobađaju se molekule koštanih biljega. Područje mjerenja razina koštanih biljega u sinovijskoj tekućini i perifernoj krvi bitan su dio istraživanja kosti u suvremenoj kliničkoj medicini i uvelike se razvija posljednjih godina. Namjera ovoga rada je dati najnoviji pregled u području sinovijske tekućine i koštanih biljega u serumu kod najčešćih artropatija.

Ključne riječi: Sinovijska tekucina; Kosti; Zglob, bolesti 